OPEN ACCESS

Edited by:

Daniel Munblit,

I. M. Sechenov First Moscow State

Medical University, Russia

Reviewed by:

Belinda van't Land,

University Medical Center Utrecht,

Netherlands

Gert Folkerts,

Utrecht University, Netherlands

${ }^{*}$ Correspondence:

R. J. Joost van Neerven

joost.vanneerven

@frieslandcampina.com

Specialty section

This article was submitted to

Pediatric Immunology,

a section of the journal

Frontiers in Pediatrics

Received: 25 April 2018

Accepted: 08 June 2018

Published: 02 July 2018

Citation:

Triantis V, Bode $L$ and

van Neerven RJJ (2018)

Immunological Effects of Human Milk

Oligosaccharides.

Front. Pediatr. 6:190

doi: 10.3389/fped.2018.00190

\section{Immunological Effects of Human Milk Oligosaccharides}

\author{
Vassilis Triantis $^{1}$, Lars Bode ${ }^{2}$ and R. J. Joost van Neerven ${ }^{1,3 *}$ \\ ${ }^{1}$ FrieslandCampina, Amersfoort, Netherlands, ${ }^{2}$ Department of Pediatrics, University of California, San Diego, San Diego, CA, \\ United States, ${ }^{3}$ Wageningen University and Research, Cell Biology and Immunology, Wageningen, Netherlands
}

Human milk oligosaccharides (HMOs) comprise a group of structurally complex, unconjugated glycans that are highly abundant in human milk. HMOs are minimally digested in the gastrointestinal tract and reach the colon intact, where they shape the microbiota. A small fraction of HMOs is absorbed, reaches the systemic circulation, and is excreted in urine. HMOs can bind to cell surface receptors expressed on epithelial cells and cells of the immune system and thus modulate neonatal immunity in the infant gut, and possibly also sites throughout the body. In addition, they have been shown to act as soluble decoy receptors to block the attachment of various microbial pathogens to cells. This review summarizes the current knowledge of the effects HMOs can have on infections, allergies, auto-immune diseases and inflammation, and will focus on the role of $\mathrm{HMOs}$ in altering immune responses through binding to immune-related receptors.

Keywords: human milk oligosaccharides, HMO, infection, immunity, infant, allergy, benefit, health

\section{INTRODUCTION}

Based on its richness in immune-related components like human milk oligosaccharides (HMOs), milk proteins and lipids, breastmilk can be seen as the first functional food humans encounter during their life (1). HMOs comprise a group of structurally complex, unconjugated glycans found in human breastmilk (see Figure 1). Although the amount and precise composition of HMOs varies depending on time of lactation and the genetic makeup of each woman as well as potential environmental exposures, human breast milk contains an average of 5-15 g of oligosaccharides per liter, making HMOs the third most abundant solid component of breast milk after lactose and lipids (2). Each oligosaccharide is built on a lactose backbone expanded by the addition of galactose, $\mathrm{N}$-acetylglucosamine, fucose or sialic acid, branched and elongated in different ways, generating approximately 200 different structures identified to-date (3). As they are only minimally digested in the gastrointestinal tract, HMOs reach the colon intact or are absorbed in small quantities, reach the systemic circulation and are excreted in urine (4). In this way, they may exert a plethora of functions at multiple sites throughout the body and beyond the intestinal lumen and intestinal mucosal surfaces, including the urinary tract or the immune system. HMOs were first described as prebiotic substrates for the infant gut microbiota, promoting the establishment of bifidobacteria and lactobacilli, based on striking differences in microbiota composition between breastfed and bottle fed infants (5).

However, HMOs are now recognized to have various additional benefits for the developing neonate. HMOs may modulate neonatal immunity by altering host epithelial and immune cell responses in the infant gut (6), modify immune responses systemically or act as soluble decoy receptors to block the attachment of various microbial pathogens to cell surface receptors (7), not only in the intestine but also in other sites such as the urinary tract (8). The benefits of HMOs can 
extend to health outcomes beyond infancy such as allergies (9) or cognitive functions (10), making HMOs the focus of intense current scientific research with increasing number of studies unraveling their role in human physiology.

This review summarizes recent findings, discusses the proposed modes of action, and identifies future prospects and scientific challenges, with a focus on immunity and infection.

\section{HMO ABSORPTION}

HMOs are resistant to digestion in the infant GI tract (11). Both neutral and acidic HMOs can cross the epithelial barrier, but active transport over intestinal epithelial monolayers has only been demonstrated for neutral HMOs (12). These findings suggest that HMOs may be taken up into the human body. Indeed, HMOs have been detected in feces and urine of breastfed infants (13-17), but also directly in the peripheral blood (18-21). However, lower concentrations of HMOs are detected in blood compared to urine, which may be a reflection of accumulation in urine from a larger volume of blood. For example, concentrations of $2^{\prime}$-fucosyllactose $\left(2^{\prime} \mathrm{FL}\right)$, were around $1.5 \mathrm{mg} / \mathrm{l}$ in peripheral blood and $100 \mathrm{mg} / \mathrm{l}$ in urine (20).

Absorption of orally administrated single HMOs was also shown in an adult rat model showing indeed that the intestinal epithelium is permeable to HMOs although to a different extent in infancy and adulthood (22). Therefore, these publications indicate that HMOs may, in addition to effects in the GI tract, have effects throughout the human body. Such effects can be conveyed directly through binding to receptors for HMOs, or indirectly via induction of short chain fatty acids and other metabolites produced by the microbiota.

\section{POTENTIAL HMO RECEPTORS, THEIR EXPRESSION AND FUNCTION}

\section{Potential HMO Receptors}

Several classes of lectins (glycan-binding proteins) have been described in the literature that have different functions and ligand specificities, namely galectins, siglecs, c- type lectins, and selectins. Different HMOs can bind to these different types of receptors on human cells, primarily expressed on cells of the immune system.

Galectins are lectins that bind $\mathrm{N}$-acetyllactosamine or lactose containing sugars (23-25). Galectins can also bind sulfated, sialylated or fucosylated galactose moieties (25). The work of Hirabayashi et al elegantly shows the oligosaccharide specificity of galectins for several HMO structures $(23,25,26)$. More recently, Prudden et al. confirmed binding of HMOs with a terminal type 1 and 2 LacNAc to galectin 9 with a preference for type 1 structures on a solid surface (27). Similar findings were reported for HMO binding specificity for galectins in solution, corroborating these initial studies $(28,29)$.

Another family of lectins involved in HMO binding are the sialic acid binding immunoglobulin- like lectins (Siglecs). Siglecs have been shown to bind sialylated HMOs (30). Sialyllactose has been shown to bind to sialoadhesin (Siglec-1) (31), but also to Siglec-5 and Siglec-10 (32), Siglec-7 (33), and Siglec-9 (34). However, the affinity of sialyllactoses for Siglecs are relatively low.

In addition to galectins and siglecs, HMOs also interfere with another family of lectins involved in cell adhesion, the selectins $(2,35)$. Selectins bind to glycans that carry sialylated Le bloodgroup epitopes (36), which are sialylated and fucosylated lacto-N-bioses (Gal $\beta 1-3 \mathrm{GlcNAc})$ or N-acetyllactosamines (GalB1-4GlcNAc)-very similar to HMOs. In fact, HMOs contain Le blood group antigens (37) and are able to reduce selectin-mediated cell-cell interactions $(38,39)$. In addition, HMOs have been shown to interact with selectins (40), and integrins (39).

Finally, HMOs can bind to C-type lectins like DC-SIGN and Dectin-1. C-type lectins containing an EPN-motif (Glu-ProAsn) have high specificity for mannose- and fucose terminating glycans, whereas the presence of a QPD-motif (GlnPro-Asp) is important for galactose-or N-acetylgalactosamine(GalNAc) terminating glycans (41). HMOs were shown to bind specifically to DC-SIGN expressed by DCs (42). Although HMO binding to DC-SIGN seems to be weaker than binding to galectins, it was shown that structures containing $\alpha$-linked fucose could bind to DC-SIGN (34). The results were also confirmed by binding of DC-SIGN to beads derivatized with $2^{\prime}$-FL or 3-FL, but not with LNT.

A limited number of reports have also discussed the possibility of binding of HMOs to other receptors belonging to the Toll like receptor (TLR) family that typically bind to pathogenrelated molecules. TLR- 4 dependent effects of HMOs have been described in two papers in which HMOs tested in vivo required the expression of TLR- 4 for their effect $(43,44)$. However, formal demonstration of the binding of the HMOs ( $3^{\prime} \mathrm{SL}$ and LNFPIII) to TLR-4 in direct binding assays was not provided. In addition, in relation to TLR-signaling of HMOs, a recent paper highlighted the effect that low level LPS contamination of the commercially available HMO $3^{\prime} \mathrm{SL}$ can have in these studies, indicating that caution is warranted when studying TLR-mediated effects (45).

An overview of putative receptors for HMO is shown in Table 1.

\section{Expression Profiles and Functions of Potential HMO Receptors}

Galectins are mainly expressed on $\mathrm{T}$ cells, and can regulate $\mathrm{T}$ cell function (46), but are also present on intestinal epithelial cells (47-49), and on antigen presenting cells and granulocytes (25). Galectins can convert signals into the cell after binding to their ligands directly, but galectins can also be secreted, after which they bind to glycoproteins or receptors at cell surfaces and hence can regulate cell functions (50-52). Binding of HMOs or lactose can thus have direct effects or inhibit the interaction of galectins with their ligands on other cells.

Siglecs are involved in the immune system in multiple ways (53). Siglecs 1-16 are expressed on a variety of blood cells, including monocytes, macrophages, dendritic cells, neutrophils, eosinophils, basophils, and NK cells $(53,54)$. In contrast to galectins and Dectin-1, Siglecs are not expressed by intestinal epithelial cells. Many of the Siglecs have an intracellular 


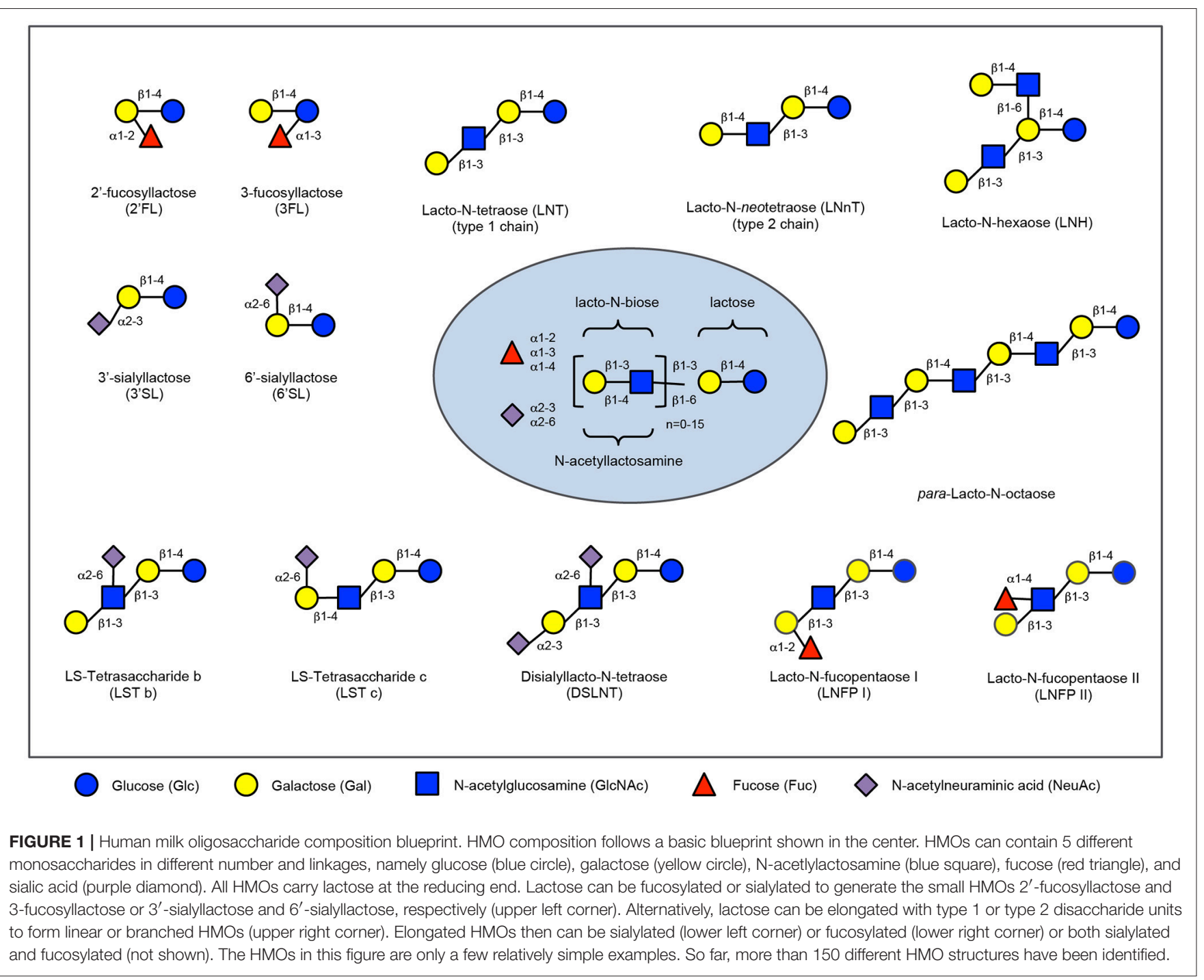

immunoreceptor tyrosine-based inhibitory motif (ITIM), and are thus known as regulators of immune responses.

Selectins are cell adhesion molecules that mediate the earliest stages of leukocyte trafficking. At sites of inflammation, leukocytes need to migrate from the blood stream through the endothelium into sub endothelial regions of inflammation $(55,56)$. Induced by pro-inflammatory cytokines, endothelial cells express P- and E-selectin, which bind to glyco-conjugates on leukocytes passing by with the blood stream. This initial contact decelerates the leukocytes and makes them roll over the endothelial cell layer. Subsequently, additional adhesion molecules bring leukocytes to a complete stop and facilitate their transmigration into sub endothelial regions. Initial selectinmediated rolling is essential for leukocyte extravasation and mucosal infiltration.

Sialylated HMOs have been shown to interact with selectins (40), and integrins (39), and affect leukocyte-endothelial cell and leukocyte-platelet interactions (39, 57-59). Similarly, sialylated HMOs reduce PNC formation and subsequent neutrophil activation in an ex vivo model with whole human blood (38). In both cases, non-sialylated HMOs are ineffective and pooled HMOs are more effective than monovalent sialyl-Le X, indicating the importance of Sia and suggesting potential multivalent interactions with higher molecular HMOs that carry more than one sialylated blood group epitope.

C-type lectins are primarily expressed by antigen presenting cells (monocytes, macrophages, dendritic cells) and are of crucial importance for regulating immune responses to pathogens. The can be divided into four subgroups, the sialo-glycoprotein receptor family (e.g., DC-SIGN), the dectin-1 subfamily of asialo glycoprotein receptors (e.g., Dectin-1), the DCIR subfamily (e.g., DCIR), and the Mannose receptor family (e.g., CD206) for a review see Geijtenbeek and Gringhuis (60).

In general, $\mathrm{c}$ - type lectins are primarily expressed on dendritic cells and macrophages, and play a role in the internalization of saccharide-containing antigens, resulting in antigen presentation (41). However, dectin-1 can also be detected on intestinal epithelial and on $\mathrm{M}$ cells, and play a role in IgA transcytosis 
TABLE 1 | Putative receptors for HMOs on the immune system.

\begin{tabular}{|c|c|c|c|c|c|c|}
\hline Type of lectin & Name & $\begin{array}{l}\text { Function of } \\
\text { receptor }\end{array}$ & Ligand specificity & Known HMO ligands & Expression & Reference \\
\hline C-type lectins & DC-SIGN & $\begin{array}{l}\text { Immune (Antigen } \\
\text { presentation) }\end{array}$ & $\begin{array}{l}\alpha \text {-fucosylated structures, } \\
\text { mannose }\end{array}$ & $\begin{array}{l}\text { 2'-FL, 3FL, LNFP-III, LNFP-IV, } \\
\text { LNDFH-I }\end{array}$ & Antigen presenting cells & (34) \\
\hline Siglecs & $\begin{array}{l}\text { Siglec-5, } \\
\text { Siglec-9 }\end{array}$ & Immune & $\begin{array}{l}\text { sialylated } \mathrm{HMO}, \alpha 2,3-\text { and } \\
\alpha 2,6 \text {-linked sialic acids }\end{array}$ & $3^{\prime}$ and $6^{\prime}$ Sialyllactose & $\begin{array}{l}\text { Neutrophils, monocytes, } \\
\text { dendritic cells }\end{array}$ & (34) \\
\hline Galectins & $\begin{array}{l}\text { Galectins } \\
1,2,3 \\
7,8.9\end{array}$ & Immune & $\mathrm{N}$-acetyllactosamine or lactose & $\begin{array}{l}\text { LNnT LNT NFP-I LNFP-II } \\
\text { LNFP-III LNDFH FucLac } \\
\text { a-GalLac but not 6SL }\end{array}$ & $\begin{array}{l}\text { Intestinal cells, lymphocytes, } \\
\text { antigen presenting cells }\end{array}$ & $(23,25,26)$ \\
\hline Selectins & & $\begin{array}{l}\text { Leucocyte } \\
\text { adhesion }\end{array}$ & $\begin{array}{l}\text { Sialylated and fucosylated } \\
\text { lacto-N-bioses (Galß1-3GlcNAc) } \\
\text { or N-acetyllactosamines }\end{array}$ & sialyl-Lewis $\mathrm{x}$ & Leucocytes, endothelium & $(37,39)$ \\
\hline
\end{tabular}

(61-63). Apart from promoting antigen presentation, some c- type lectins like DCIR may-just like Siglecs-contain an immunoreceptor tyrosine-based inhibitory motif (ITIM) -motif in their intracellular domains, that inhibit immune activation.

DC-SIGN interacts with a variety of pathogens, including HIV-1, and binding of HMOs inhibited the transfer of HIV1 to $\mathrm{CD} 4+\mathrm{T}$ lymphocytes. These data may suggest that oligosaccharides act systemically and are thereby modulating the immune response in a microbiota-independent manner. In addition, recent publications have also demonstrated that the c-type lectin Dectin-1 can modulate innate immune function, possibly explaining the cross-protection against other pathogens seen after vaccination $(64,65)$.

The functions of these receptors thus indicates that binding of HMOs to these structures may result in regulation of adaptive and innate immune protection against infection and inflammation.

\section{EFFECTS OF HMOS ON INFECTION, ALLERGY AND IMMUNE PARAMETERS IN HUMAN STUDIES}

As can be seen in Table 2, there are currently only a few infant studies on effects of HMOs on infection and immune function. Most of these studies are observational studies on breastfeeding infants, correlating HMOs in breastmilk with these outcomes. Placebo controlled studies with HMOs have been performed but have to date focused on safety rather than on anti-infective and immunomodulatory effects $(18,77)$.

Four of these studies showed an effect of HMOs on prevention of diarrhea $(67,69)$, respiratory tract infections $(69)$, and severe outcomes like sepsis and death (75). Morrow et al. showed in another study that HIV exposed, non-infected children receiving breastmilk of secretor + mothers have a reduced risk of early mortality compared to secretor-breastfeeding (66).

Also, in relation to cow's milk allergy, the level of Lacto$\mathrm{N}$-fucopentaose (LNFP) III in breast milk correlated with the prevalence of cow's milk allergy (9). Similarly, Sprenger et al. reported that FUT2-dependent breast milk oligosaccharides, with the levels of $2^{\prime} \mathrm{FL}$ as proxy for secretor status, were associated with lower levels of IgE-mediated allergies and eczema (70).

Finally, Biesbroek et al. reported recently that 6 week old breastfed children have a different nasopharyngeal microbiota, suggesting that milk components like HMOs may influence the nasopharyngeal microbiota composition-which may contribute to the protective effect of breastfeeding on decreased respiratory infections (76).

It should be stressed that none of these studies have formally demonstrated direct effects of HMOs, and that other breastfeeding components may be associated with the effects described. Only in a recent study (71) the administration of 2 FL in combination with LNnT could reversely correlate with parentally reported episodes of bronchitis, lower respiratory tract infections, and use of antipyretics or antibiotics at different ages.

However, as reviewed in detail in section Effects of HMOs on Infection, Allergy and Immune Parameters in Human Studies and in several recent reviews (2, 35, 7888), quite some information is available of effects of effects of HMOs on microbiota composition, pathogens, and pathogen adhesion in vitro, as well as on infection in vivo. In addition, effects on intestinal epithelium and barrier function, as well as immune function have been described in these reviews and the underlying literature.

In infants another study showed that the secretor or nonsecretor genotype of mothers of infants that were breastfed correlated with enterocolitis (low secretor) and sepsis (nonsecretor) (66).

It has been shown as well that the amount of 2-linked fucosylated oligosaccharides in breast milk inversely correlates with the incidence of diarrhea in infants (89), and similarly the amount of fucosyl oligosaccharides in breast milk inversely correlates with the severity of infection with $\mathrm{E}$ coli that has a stable (68). Similarly, the amount of 2FL inversely correlated with Campylobacter diarrhea (89).

Bode et al demonstrated that the risk of HIV transmission in breastfeeding children of HIV infected mothers inversely correlates with HMO concentration (73). In another study the amount of LDFH-1 in breast milk inversely correlated with norovirus diarrhea (67). In addition to effects of HMOs on 


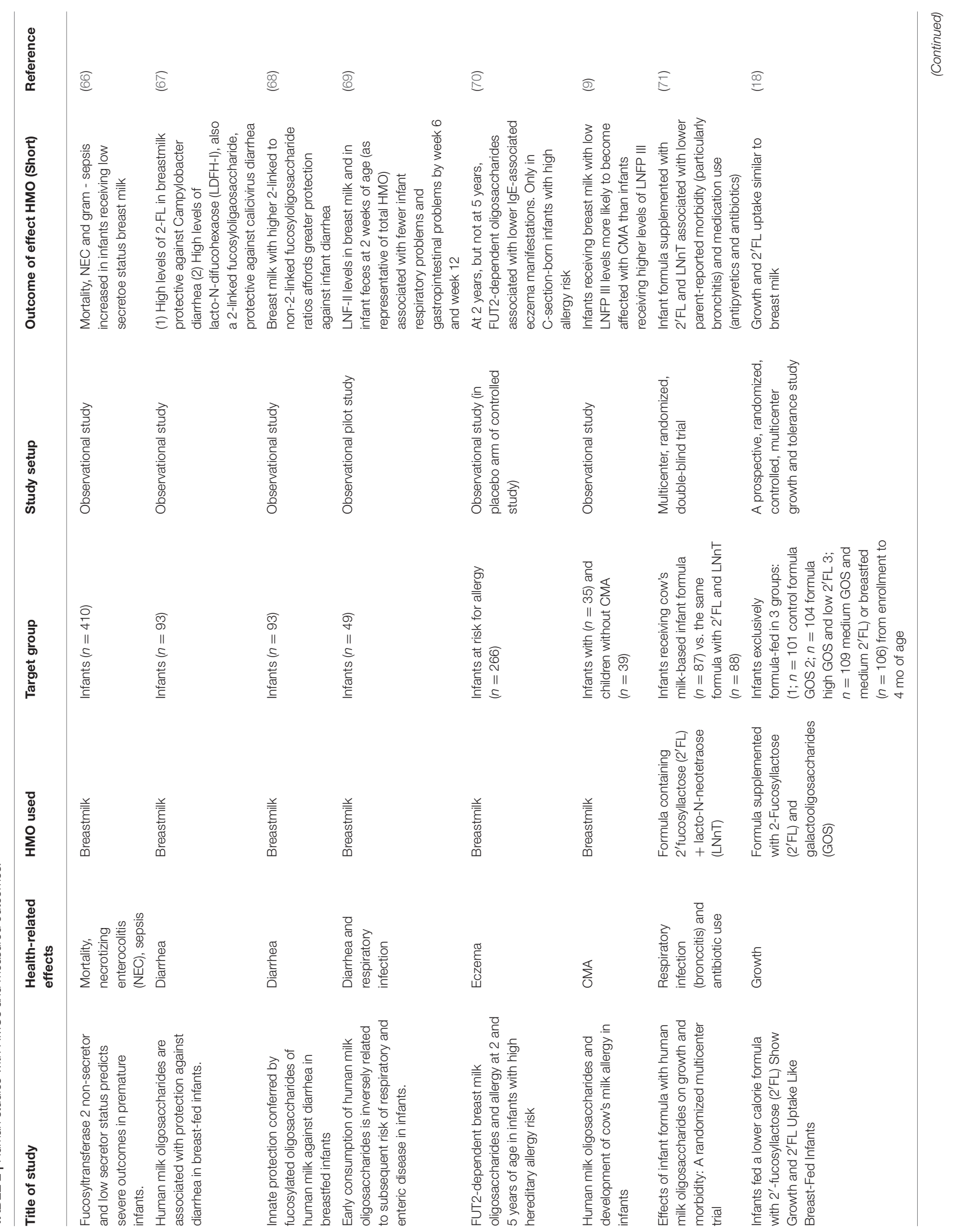




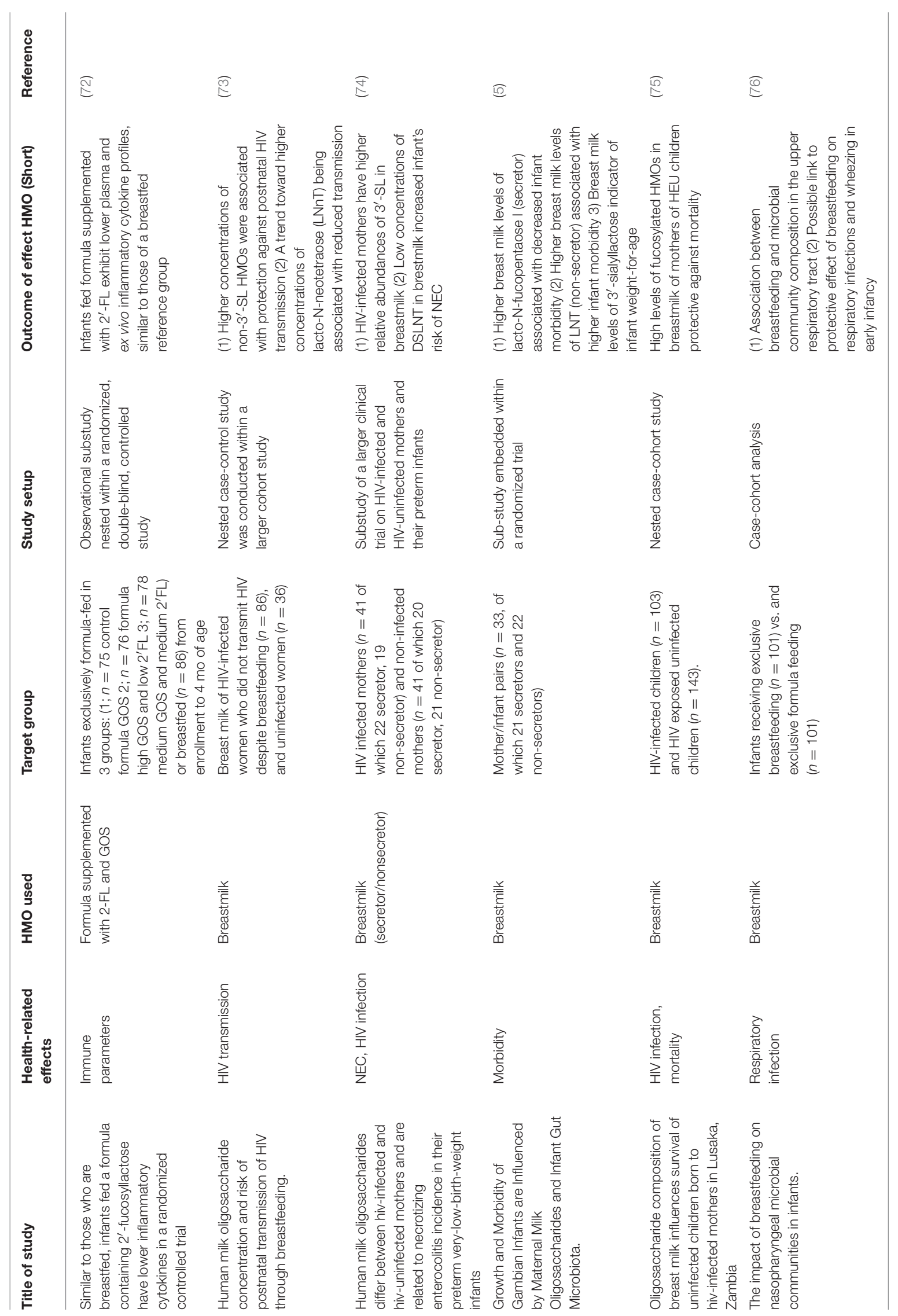


intestinal infections, HMOs have been linked to other infections such as infections of the urogenital tract $(8,90)$, and airway infection $(69,91,92)$.

Such results were expanded lately with measuring inflammatory cytokines in systemic circulation if infants receiving infant formula supplemented with $2^{\prime}$-FL (72).

Much more is known about the direct effects of HMOs on pathogens, on adhesion and infection in in vitro models, and in animal models.

\section{EFFECTS OF HMOS ON IMMUNE FUNCTION AND INFECTION IN IN VITRO AND ANIMAL STUDIES}

\section{Effects on Bacterial Adhesion and Infection}

HMOs have been shown to prevent adhesion of several potential pathogens to epithelial surfaces in the intestine and other organs by acting as decoy receptors for bacterial pathogens like Campylobacter or E. coli (86, 93-95).

Several recent manuscripts report specific effects of isolated HMOs. For example, Weichert et al. showed that $2^{\prime} \mathrm{FL}$, and to a lesser extent 3FL, reduce the adhesion of Campylobacter, EPEC, Salmonella and Pseudomonas, although the inhibitory effects were very small (96). Sialylated oligosaccharides were shown to reduce adhesion of $\operatorname{EPEC}(97,98)$. In addition to reducing the adhesion of entire bacteria, HMOs may also compete with binding of bacterial toxins and mitigate their diarrheal activity $(99,100)$.

However, not always is the beneficial effect of HMOs to bacterial infection arising from preventing association or invasion of the pathogen. For example, HMOs can alter gene expression in intestinal cells that can block infection of Listeria monocytogenes (101), or have a direct effect on the growth of pathogens as was shown for neutral HMOs and especially LNT and LNFP I against group B Streptococcus (102). Similarly, HMOs were shown to modulate hyphal induction in Candida albicans, which is necessary for invasion of the intestinal epithelium (103). Another mechanism could be attenuation of pathogenic virulence through metabolites from fermentation of HMOs from the intestinal microflora. That seems to be at least partially the case for Escherichia coli O157:H7 and Salmonella typhimurium (104). When bifidobacteria of human and bovine origin were grown on medium containing $3^{\prime}$-SL, they could produce metabolites that could block expression of virulence genes in both pathogens. In addition, HMOs may have an indirect effect on bacterial infection by reducing epithelial inflammatory responses as it has been shown for $2^{\prime}$-FL and Campylobacter-induced inflammation (105).

While 2 -FL protected against adherent-invasive E. coliinduced pathology in mice (106), it failed to improve E. coliinduced diarrhea in piglets (107). These contradicting results could be explained by the difference in model, virulence of different E. coli strains, dosage and timing of administration of pathogens and HMOs, etc.

\section{Effects on Intestinal Viruses}

Shang et al. demonstrated that different HMOs can bind to norovirus (LNFPII and $2^{\prime}$ FL) and Norwalk virus (LNFP I and LNDFHI), indicating that several potential Noro- and Norwalk virus-binding glycans are present in HMOs that can play a role in viral infection (108). Notably, they also showed that LNFP IIIHSA and $2^{\prime}$-FL-BSA - but not heir monovalent forms (LNFP III-Gly and 2'-FL-Gly) bound to VA287 capsids. This suggests that polyvalent oligosaccharides on a carrier protein may be more potent in anti-adhesion effects than their monovalent sugars themselves. However, recently it was also shown that $2^{\prime}$-FL can block both the GI.1 and GII.17 noroviruses from binding to HBGAs (109).

In addition to effects on gut bacteria, HMOs can also have effects on viral pathogens as rotavirus, norovirus, and HIV [reviewed in (85)].

In Rotavirus infected piglets, HMO-supplemented piglets had a shorter duration of diarrhea compared to the control Group $(110,111)$. There have been several HMO structures identified that bind the glycan rotaviral receptor VP8*. The sialic acid containing HMOs inhibited rotavirus infection in vitro, but in vivo both neutral HMOs and sialic acid containing HMOs decreased replication during acute RV infection in situ. These data are confirmed by recent in vitro findings where $2^{\prime}-\mathrm{FL}, 3^{\prime}$ SL, and $6^{\prime}$-SL could block infectivity of human rotaviral strains in cells (7). Apparently simple HMO structures can act as decoy receptors for viruses. However, since there are differences in the infectious mechanism of porcine and human rotaviral strains extrapolation from porcine to human models can be treacherous and more research is needed to clarify the role of HMOs in rotaviral infections.

\section{Effects on Respiratory Viruses}

In addition to effects on intestinal pathogens, HMOs have been suggested to also play a role in infections from respiratory viruses. For example, 2'FL was shown to decrease RSV viral load, whereas LNnT and 6'SL decreased influenza viral load. Also effects were observed on innate cytokines in response to both viruses (92) suggesting an effect of HMOs on respiratory virus infection. This is supported by an early study by StepansFlanders on the fact that HMO consumption is inversely linked to respiratory infection (69). In this study higher LNFPII levels in breastmilk correlated with decreased respiratory and gastrointestinal infections in early infancy.

Immobilized $3^{\prime}$ SL and 6'SL haven been shown to prevent infectivity of influenza viruses as a result of blocking the haemagglutins of influenza viruses $(112,113)$, and Yu et al. identified a number of additional sialic acid containing HMOs that bind to influenza virus (114). The effects of these HMOs was confirmed in a functional infection assay in vitro, where 6'SL and LNnT were shown to reduce the viral load of influenza in airway epithelial cells, and $2^{\prime} \mathrm{FL}$ did the same for respiratory syncytial virus (RSV) (92). In one recent in vivo study $2^{\prime} \mathrm{FL}$ enhanced responses to vaccination in mice (115). The mechanism was postulated to involve also a direct effect of $2^{\prime} \mathrm{FL}$ on dendritic cells as shown in vitro. However, concentrations used in their experiments were more than 1000 -fold higher than what has 
been described to be found in circulation (20), warranting further clarification and research on the mechanism of action and relevance to human breast-fed infants.

\section{Enterocolitis}

In relation to necrotizing enterocolitis, Jantscher-Krenn et al. noted in a rat model that disialylated LNT (DSLNT) increased survival rates and improved pathology scores (116), while low amounts of DSLNT in mother's milk could be a predicting risk factor for the development of NEC in premature infants (117) corroborating the previous findings. More HMOs could have a beneficial effect in NEC as it was shown also in a rat study where $2^{\prime}$-FL ameliorated the pathology of NEC, however there was no association between $2^{\prime} \mathrm{FL}$ and NEC risk in the corresponding human cohort (115). Similar observations were made for rats fed sialylated galacto-oligosaccharides (Sia-GOS) (118). Studies in mice have also shown a beneficial effect of $2^{\prime}$-FL in an induced NEC model (119). However such effect could not be seen in a piglet model where piglets born with caesarian section were fed control formula or formula supplemented with $2^{\prime}$-FL and were let to develop NEC spontaneously (120). Differences between induction vs. natural progression to NEC or species differences could account for such outcomes. In infants another study showed that the secretor or non-secretor genotype of mothers of infants that were breastfed correlated with enterocolitis (low secretor) and sepsis (non-secretor) (66).

\section{Effects of HMOs on Intestinal Epithelium}

In another study immunomodulation by $2^{\prime} \mathrm{FL}$ in vivo was shown to be dependent on the downregulation of CD14 on intestinal epithelial cells (106). As CD14 is a co-receptor for LPS and is involved in TLR-4 signaling, this may lead to decreased inflammatory responses in the intestine after exposure to LPS.

In a recent study by $\mathrm{He}$ et al. the effect of colostrum oligosaccharides on gene expression in fetal immature intestinal mucosa was tested (121). They identified several immune related pathways were induced by HMOs, such as Immune cell communication, homeostasis, and intestinal immune differentiation. HMOs could reduce the response to TLR stimuli, and induced cytokines that are involved in tissue repair. $3^{\prime}, 4$, and $6^{\prime}$ galatosyllactoses were the most potent oligosaccharides.

Sialyllactose has been described to be able to promote the differentiation and growth of human intestinal epithelial cells as measured by upregulation of expression of alkaline phosphatase (122). Alkaline phosphatase is a molecule that is important in maintaining gut barrier function, possibly through the inactivation of LPS, by cleaving of a phosphate group from LPS. This suggests that on the one hand epithelial cells may yet have a receptor that recognizes Sialyllactose, and that Sialyllactose may be beneficial for promoting a good epithelial barrier in the gut.

In addition, two recent papers suggest that SL or goat milk oligosaccharides containing SL may have an effect on epithelial cells via activating through $\operatorname{TLR} 4(43,123)$.

In contrast, another paper showed that $3^{\prime} \mathrm{SL}$ had antiinflammatory activity by reducing the expression of IL-12 and
IL-8 in Caco-2 cells, mediated via NFkB, and stimulates the antiinflammatory nuclear receptor PPARg (124). Especially neutral HMOs have been shown to have an anti-inflammatory effects on the intestinal epithelium in in vitro inflammatory models $(106,121)$.

Lane compared effects of HMOs and BMOs on gene expression in HT-29 cells, noting that "both treatments including a response to stimulus, signaling, locomotion, and multicellular, developmental and immune system processes" (125).

Combined, these studies suggests that milk oligosaccharides contribute to the development and maturation of the intestinal immune response.

\section{Effects of HMOs on Immune Function}

Acidic HMOs (but not acidic cow's milk oligosaccharides) were shown to induce IFN-g and IL-10 in human cord blood T cells, and could decrease IL-4 production in allergen-specific $T$ cells (126). These data suggest that acidic HMOs may downregulate Th2 responses in infants as well.

Such results were expanded lately with measuring inflammatory cytokines in systemic circulation if infants receiving infant formula supplemented with $2^{\prime}$-FL (72). In this study, supplementation of $2^{\prime}$-FL alone could lower levels of TNF $\alpha$, IL- $1 \alpha$, IL- $1 \beta$, and IL- 6 resembling those found in breast fed infants. In early studies LNFP III and LNnT were shown to have immunosuppressive effects $(127,128)$, and LNFPIII can induce IL-10 in macrophages $(129,130)$. Unexpectedly, a link with helminth infections exists. It is now known that upon infection with helminths confers a protective effect on allergy development $(131,132)$. Schistosoma eggs, but not the helminth itself, induce potent IL-10 responses that inhibit Th2 responses $(133,134)$. These effects are at least in part mediated by the oligosaccharides LNFPIII GalNAc $\beta 1$-4(Fuc $\alpha 1-2$ Fuc $\alpha 1-3)$ GlcNAc (LDN-DF) and Lewis-X that is present in the egg shells. These oligosaccharides are also found in breast milk, suggesting a functional anti-allergic/anti-inflammatory role of these HMOs. Likewise, Comstock et al. demonstrated a similar effect of HMOs in vivo in piglets, where HMOs induced IL-10 levels and inhibited $\mathrm{T}$ cell proliferation (135). The same was noted by Hester et al that showed enhanced $\mathrm{T}$ helper type 1 (interferon-gamma) and anti-inflammatory (interleukin-10) cytokines in the ileum in response to HMO supplementation of piglets in a rotavirus infection model (110).

Interestingly, LNFPIII and Lewis $\mathrm{X}$ glycoconjugates can also inhibit TLR signaling in innate immune cells through possible involvement of c-type lectins (132). LNFPIII is a very well-studied HMO that has been linked to many different effects including hepatosteatosis and insulin resistance (136), autoimmunity (137), and transplantation (138). Especially in the case of insulin resistance and autoimmunity, HMOs have been shown to elicit a protective effect in a murine model of Type 1 Diabetes (T1D) (139). The paper shows that supplementation of HMOs can alter microbiota composition and SCFA production in a NOD-mouse model that can prevent spontaneous progression to diabetes. The protective effect of SCFA-producing diets on T1D has been documented beforehand $(140,141)$. On the other hand, by increasing barrier integrity 
HMOs may also reduce gut permeability, which has been argued to contribute to the onset of T1D (142).

\section{Indirect Effects of HMOs on Intestinal Epithelium and Immune Function via SCFA}

Another important role of HMOs is establishing and maintaining the intestinal microbiota. Breastfed infants have higher numbers of beneficial bifidobacteria and lactobaccilli than bottle fed infants. This is the result of preferential fermentation of HMOs by the microbiota by bifidobacterial and lactobacilli (143-145). Upon fermentation of HMOs these bacteria produce, in addition to lactic acid, the short chain fatty acids (SCFA) butyrate, actetate, and propionate. These SCFA improve intestinal barrier function (146) lower the $\mathrm{pH}$ in the colon, and have well established anti-inflammatory properties (147).

The notion that composition and metabolic activity of the intestinal microbiota affects the development of allergies has become clearer over the last years (148-151). Exactly how the microbiota composition influences allergy development is not clear at this point, but data from animal models strongly suggest a protective role for SCFA (152-155). A similar role was shown for the SCFA receptors GPR43 in asthma, arthritis, and colitis models (156), and for GPR41 in allergic airway inflammation.

Taken together, these data suggests that HMOs may also have an indirect effect on allergy.

\section{HMOs AND ALLERGY}

Several, but not all, studies on the association between breastfeeding and allergy have shown effects on allergic outcomes (157-159). One of the factors that may explain the conflicting findings described above may be the result of differences in breastmilk composition (in relation to milk proteins) (160). None of these studies have correlated their findings with HMO composition.

However, two studies have done just this. In a cohort study of cow's milk allergy (CMA) (9) it was observed that the concentration of 6SL, DSLNT, LNFPI, and LNFPIII was lower in the breast milk of mothers having infants with CMA. After further corrections, only breast milk levels of LNFPIII associated reversely and significantly with development of CMA. In the same study it was observed that FUT2 status of mothers correlated with a delayed onset of CMA while CMA infants born to non-secretor mothers (FUT2 negative) were prone to acute CMA (IgE-mediated). FUT2 status seemed to play a role also in IgE-mediated eczema developed in infants born with C-section (70). In a study of 266 infants followed for 5 years, they observed that infants born to secretor mothers had lower incidence of IgEmediated eczema. That effect was evident at 2 years but not at 5 years of age though. $2^{\prime}$-FL (one of the main HMOs produced by secretor mothers) was shown to have a significant association with any allergic disease, acute or delayed in infants born with Csection in the same study. $2^{\prime}$-FL and $6^{\prime}$ SL had also a beneficial

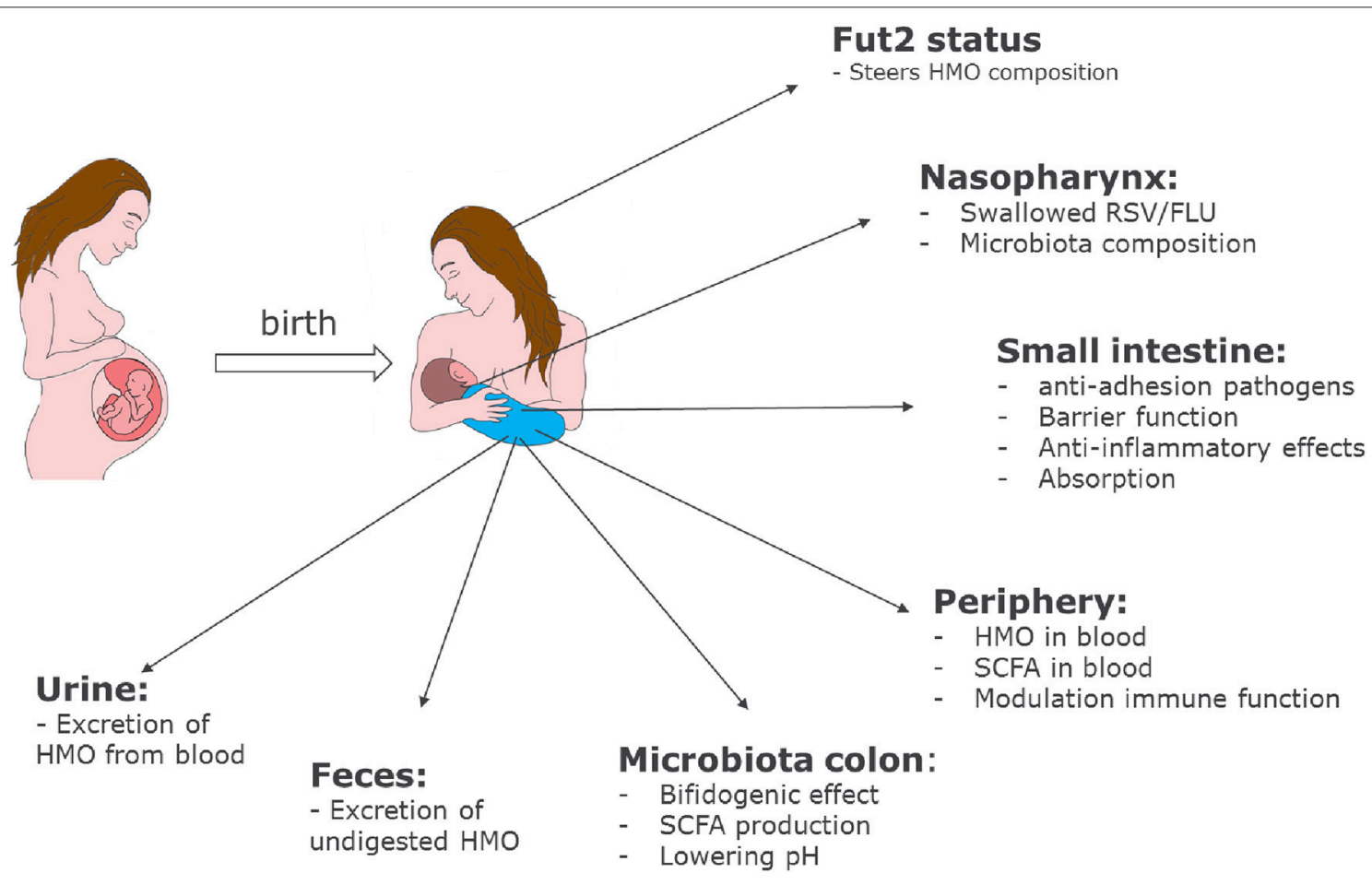

FIGURE 2 | Role of HMOs in developmental physiology of infants: Depending on the genetic background of the mother, HMO composition may differ. Depending on the HMO composition in breast milk, benefits of HMOs span a broad range from shaping the infant microbiome to preventing infections and having systemic effects in the infant after absorption in the intestine. 
effect in a mouse model of OVA-induced allergy (161). Both HMOs could increase numbers of IL10 producing Treg cells and alleviate allergic symptoms but through different mechanisms.

\section{CONCLUSIONS}

HMOs contribute to the development of the microbiota and the immune system of newborn infants. The mechanisms by which HMOs contribute have become clearer over the past few years, and our current knowledge is summarized in Figure 2.

However, despite many in vitro- and animal experiments, HMOs have not been tested extensively in placebo controlled infant studies. It is clear that several HMOs will be introduced in the near future into infant nutrition to supplement or replace non-human prebiotics like galactooligosaccharides and/or fructooligosaccharides. Prebiotics have been added to infant nutrition in the early 2000's as non-digestible oligosaccharides in an attempt to mimic some of the function of HMOs. With these prebiotics a large number of studies have shown effects on intestinal infection, respiratory infection and allergy (162-167). As the selection of prebiotics is based on functional similarities with HMOs, and extrapolating from in vitro and animal experiments with HMOs, it is to be expected

\section{REFERENCES}

1. Gura T. Nature's first functional food. Science (2014) 345:747-9. doi: 10.1126/science.345.6198.747

2. Bode L. Human milk oligosaccharides : every baby needs a sugar mama. Glycobiology (2012) 22:1147-62. doi: 10.1093/glycob/cws074

3. Ninonuevo MR, Park Y, Yin H, Zhang J, Ward RE, Clowers BH, et al. A strategy for annotating the human milk glycome. J Agric Food Chem. (2006) 54:7471-80. doi: 10.1021/jf0615810

4. Rudloff S, Pohlentz G, Borsch C, Lentze MJ, Kunz C. Urinary excretion of in vivo 13C-labelled milk oligosaccharides in breastfed infants. Br J Nutr. (2012) 107:957-63. doi: 10.1017/S0007114511004016

5. Davis EC, Wang M, Donovan SM. The role of early life nutrition in the establishment of gastrointestinal microbial composition and function. Gut Microbes (2017) 8:143-71. doi: 10.1080/19490976.2016.1278104

6. Newburg DS, Ko JS, Leone S, Nanthakumar NN. Human milk oligosaccharides and synthetic galactosyloligosaccharides contain $3^{\prime}$-, 4-, and 6'-galactosyllactose and attenuate inflammation in human T84, NCM-460, and H4 cells and intestinal tissue ex vivo. J Nutr. (2016) 146:358-67. doi: 10.3945/jn.115.220749

7. Laucirica DR, Triantis V, Schoemaker R, Estes MK, Ramani S. Milk oligosaccharides inhibit human rotavirus infectivity in MA104 cells. J Nutr. (2017) 147:1709-14. doi: 10.3945/jn.116.246090

8. Lin AE, Autran CA, Espanola SD, Bode L, Nizet V. Human milk oligosaccharides protect bladder epithelial cells against uropathogenic Escherichia coli invasion and cytotoxicity. J Infect Dis. (2014) 209:389-98. doi: 10.1093/infdis/jit464

9. Seppo AE, Autran CA, Bode L, Järvinen KM. Human milk oligosaccharides and development of cow's milk allergy in infants. J Allergy Clin Immunol. (2017) 139:708-11.doi: 10.1016/j.jaci.2016.08.031

10. Oliveros E, Ramirez M, Vazquez E, Barranco A, Gruart A, DelgadoGarcia JM, et al. Oral Supplementation of $2^{\prime}$-fucosyllactose during lactation improves memory and learning in rats. J Nutr Biochem. (2016) 31:20-7. doi: 10.1016/j.jnutbio.2015.12.014

11. Engfer MB, Stahl B, Finke B, Sawatzki G, Daniel H. Human milk oligosaccharides are resistant to enzymatic hydrolysis in the that inclusion of HMOs to infant formula will have additional benefits to infant health, and may supplement the functionality of the prebiotics that are already used. Still more research is needed to clarify whether HMOs may also have a therapeutic rather than a protective effect in human immune disorders. Our emerging evidence for the beneficial effects of HMOs once again provide a powerful rationale to encourage women to breastfeed their infants to provide the full scope of benefits that stem from a diverse composition of HMOs that is provided through mother's milk and could potentially be personalized to match the genetic context and environmental exposures of the mother-infant dyad.

\section{AUTHOR CONTRIBUTIONS}

All authors listed have made a substantial, direct and intellectual contribution to the work, and approved it for publication.

\section{ACKNOWLEDGMENTS}

The authors would like to thank D. Delsing for critically reviewing the manuscript and I. van Neerven for help with Figure 2. upper gastrointestinal tract. Am J Clin Nutr. (2000) 71:1589-96. doi: 10.1093/ajcn/71.6.1589

12. Gnoth MJ, Rudloff S, Kunz C, Kinne RK. Investigations of the in vitro transport of human milk oligosaccharides by a Caco-2 monolayer using a novel high performance liquid chromatography-mass spectrometry technique. J Biol Chem. (2001) 276:34363-70. doi: 10.1074/jbc.M104805200

13. Dotz V, Rudloff S, Meyer C, Lochnit G, Kunz C. Metabolic fate of neutral human milk oligosaccharides in exclusively breast-fed infants. Mol Nutr Food Res. (2015) 59:355-64. doi: 10.1002/mnfr.201400160

14. Albrecht S, Schols H A., Van Den Heuvel EGHM, Voragen AGJ, Gruppen $\mathrm{H}$. Occurrence of oligosaccharides in feces of breast-fed babies in their first six months of life and the corresponding breast milk. Carbohydr Res. (2011) 346:2540-50. doi: 10.1016/j.carres.2011.08.009

15. Albrecht S, Schols H A, van Zoeren D, van Lingen R A, Groot Jebbink LJM, van den Heuvel EGHM, et al. Oligosaccharides in feces of breast- and formula-fed babies. Carbohydr Res. (2011) 346:2173-81. doi: 10.1016/j.carres.2011.06.034

16. Rudloff S, Pohlentz G, Diekmann L, Egge H, Kunz C. Urinary excretion of lactose and oligosaccharides in preterm infants fed human milk or infant formula. Acta Paediatr. (1996) 85:598-03. doi: 10.1111/j.1651-2227.1996.tb14095.x

17. Rudloff S, Kunz C. Milk oligosaccharides and metabolism in infants. $A d v$ Nutr. (2012) 3:398S-05S. doi: 10.3945/an.111.001594

18. Marriage BJ, Buck RH, Goehring KC, Oliver JS, Williams JA. Infants fed a lower calorie formula with $2^{\prime} \mathrm{FL}$ show growth and $2^{\prime} \mathrm{FL}$ uptake like breast-fed infants. J Pediatr Gastroenterol. (2015) 61:649-58. doi: 10.1097/MPG.0000000000000889

19. Ruhaak LR, Stroble C, Underwood MA, Lebrilla CB. Detection of milk oligosaccharides in plasma of infants. Anal Bioanal Chem. (2014) 406:577584. doi: $10.1007 / \mathrm{s} 00216-014-8025-\mathrm{z}$

20. Goehring KC, Kennedy AD, Prieto PA, Buck RH. Direct evidence for the presence of human milk oligosaccharides in the circulation of breastfed infants. PLoS ONE (2014) 9:e101692. doi: 10.1371/journal.pone.0101692

21. Radzanowski G, Garrett P, Li X, Anita M. Short-chain milk oligosaccharide levels in human milk and infant plasma. FASEB J. (2013) 27:Abstract 629.16 
22. Vazquez E, Santos-Fandila A, Buck R, Rueda R, Ramirez M. Major human milk oligosaccharides are absorbed into the systemic circulation after oral administration in rats. Br J Nutr. (2017) 117:237-47. doi: 10.1017/S0007114516004554

23. Hirabayashi J, Hashidate T, Arata Y, Nishi N, Nakamura T, Hirashima $\mathrm{M}$, et al. Oligosaccharide specificity of galectins: a search by frontal affinity chromatography. Biochim Biophys Acta (2002) 1572:232-254. doi: 10.1016/S0304-4165(02)00311-2

24. Leffler $\mathrm{H}$, Carlsson S, Hedlund M, Qian Y, Poirier F. Introduction to galectins. Glycoconj $J$ (2002) 19:433-40. doi: 10.1023/B:GLYC.0000014072.34840.04

25. Rapoport EM, Kurmyshkina OV, Bovin NV. Mammalian galectins: structure, carbohydrate specificity, and functions. Biochemistry (2008) 73:393-05. doi: 10.1134/S0006297908040032

26. Shams-ud-doha K, Kitova EN, Kitov PI, St-pierre Y, Klassen JS. Human milk oligosaccharide specificities of human galectins. comparison of electrospray ionization mass spectrometry and glycan microarray screening results. Anal Chem. (2017) 89:4914-21. doi: 10.1021/acs.analchem.6b05169

27. Prudden AR, Liu L, Capicciotti CJ, Wolfert MA, Wang S, Gao Z, et al. Synthesis of asymmetrical multiantennary human milk oligosaccharides. Proc Natl Acad Sci USA. (2017). 114:6954-59. doi: 10.1073/pnas. 1701785114

28. El-Hawiet A, Chen Y, Shams-Ud-Doha K, Kitova E, Kitov P, Bode L, et al. Screening natural libraries of human milk oligosaccharides against lectins using CaR-ESI-MS. Analyst (2018) 143:536-48. doi: 10.1039/C7AN01397C

29. El-Hawiet A, Chen Y, Shams-Ud-Doha K, Kitova EN, St-Pierre Y, Klassen JS. High-throughput label- and immobilization-free screening of human milk oligosaccharides against lectins. Anal Chem. (2017) 89:8713-22. doi: 10.1021/acs.analchem.7b00542

30. Koliwer-Brandl H, Siegert N, Umnus K, Kelm A, Tolkach A, Kulozik U, et al. Lectin inhibition assay for the analysis of bioactive milk sialo glycoconjugates. Int Dairy J. (2011) 21:413-20. doi: 10.1016/j.idairyj.2011.01.005

31. Bhunia A, Jayalakshmi V, Benie AJ, Schuster O, Kelm SÃ, Krishna NR, et al. Saturation transfer difference NMR and computational modeling of a sialoadhesin-sialyl lactose complex. Carbohydr Res. (2004) 339:259-67. doi: 10.1016/j.carres.2003.09.021

32. Li N, Zhang W, Wan T, Zhang J, Chen T, Yu Y, et al. Cloning and Characterization of Siglec-10, a novel sialic acid binding member of the ig superfamily, from human dendritic cells *. J Biol Chem. (2001) 276:2810612. doi: 10.1074/jbc.M100467200

33. Alphey MS, Attrill H, Crocker PR, van Aalten DMF. High resolution crystal structures of Siglec-7. Insights into ligand specificity in the Siglec family. $J$ Biol Chem. (2003) 278:3372-77. doi: 10.1074/jbc.M210602200

34. Noll AJ, Yu Y, Lasanajak Y, Duska-McEwen G, Buck RH, Smith DF, et al. Human DC-SIGN binds specific human milk glycans. Biochem J. (2016) 473:1343-53. doi: 10.1042/BCJ20160046

35. Chichlowski M, German JB, Lebrilla CB, Mills D A. The influence of milk oligosaccharides on microbiota of infants: opportunities for formulas. Annu Rev Food Sci Technol. (2011) 2:331-51. doi: 10.1146/annurev-food-022510-133743

36. Varki A. Selectin ligands: will the real ones please stand up? J Clin Invest. (1997) 100:S31-5. doi: 10.1172/JCI119142

37. Rudloff S, Stefan C, Pohlentz G, Kunz C. Detection of ligands for selectins in the oligosaccharide fraction of human milk. Eur J Nutr. (2002) 41:85-92. doi: $10.1007 / \mathrm{s} 003940200012$

38. Bode L, Rudloff S, Kunz C, Strobel S, Klein N. Human milk oligosaccharides reduce platelet-neutrophil complex formation leading to a decrease in neutrophil beta 2 integrin expression. J Leukoc Biol. (2004) 76:820-6. doi: 10.1189/jlb.0304198

39. Bode L, Kunz C, Muhly-Reinholz M, Mayer K, Seeger W, Rudloff S. Inhibition of monocyte, lymphocyte, and neutrophil adhesion to endothelial cells by human milk oligosaccharides. Thromb Haemost. (2004) 92:1402-10. doi: 10.1160/TH04-01-0055

40. Schumacher G, Bendas G, Stahl B, Beermann C. Human milk oligosaccharides affect P-selectin binding capacities: in vitro investigation. Nutrition (2006) 22:620-7. doi: 10.1016/j.nut.2005.12.009
41. van Kooyk Y, Rabinovich GA. Protein-glycan interactions in the control of innate and adaptive immune responses. Nat Immunol. (2008) 9:593-601. doi: 10.1038/ni.f.203

42. Naarding MA, Ludwig IS, Groot F, Berkhout B, Geijtenbeek TBH, Pollakis G, Paxton WA. Lewis X component in human milk binds DC-SIGN and inhibits HIV-1 transfer to CD4 + T lymphocytes. J Clin Invest. (2005) 115:3256-64. doi: 10.1172/JCI25105

43. Kurakevich E, Hennet T, Hausmann M, Rogler G, Borsig L. Milk oligosaccharide sialyl $(\alpha)$ lactose activates intestinal CD11c+ cells through TLR4. Proc Natl Acad Sci USA. (2013) 110:17444-9. doi: $10.1073 /$ pnas. 1306322110

44. Thomas PG, Carter MR, Atochina O, 'Dara AA, Piskorska D, McGuire E, Harn DA. Maturation of dendritic cell 2 phenotype by a helminth glycan uses a Toll-like receptor 4-dependent mechanism. J Immunol. (2003) 171:583741. doi: 10.4049/jimmunol.171.11.5837

45. Perdijk O, van Neerven RJJ, Meijer B, Savelkoul HFJ, Brugman S. Induction of human tolerogenic dendritic cells by $3^{\prime}$-sialyllactose via TLR4 is explained by LPS contamination. Glycobiology (2018) 28:126-30. doi: 10.1093/glycob/cwx106

46. Rabinovich, GA. and Toscano, MA. Turning sweet on immunity : galectin glycan interactions in immune tolerance and inflammation. Nat Rev Immunol. (2009) 9:338-52. doi: 10.1038/nri2536

47. Delacour D, Koch A, Ackermann W, Eude-Le Parco I, Elsasser H-P, Poirier F, et al. Loss of galectin-3 impairs membrane polarisation of mouse enterocytes in vivo. J Cell Sci. (2008) 121:458-65. doi: 10.1242/jcs.020800

48. Huflejt ME, Jordan ET, Gitt MA, Barondes SH, Leffler H. Strikingly different localization of galectin-3 and galectin-4 in human colon adenocarcinoma T84 cells. Galectin-4 is localized at sites of cell adhesion. J Biol Chem. (1997) 272:14294-303. doi: 10.1074/jbc.272.22.14294

49. Wasano K, Hirakawa Y. Recombinant galectin-1 recognizes mucin and epithelial cell surface glycocalyces of gastrointestinal tract. J Histochem Cytochem. (1997) 45:275-83. doi: 10.1177/00221554970 4500212

50. Lahm H, Andre S, Hoeflich A, Fischer JR, Sordat B, Kaltner H, et al. Comprehensive galectin fingerprinting in a panel of 61 human tumor cell lines by RT-PCR and its implications for diagnostic and therapeutic procedures. J Cancer Res Clin Oncol. (2001) 127:375-86. doi: 10.1007/s004320000207

51. Lippert E, Falk W, Bataille F, Kaehne T, Naumann M, Goeke M, et al. Soluble galectin-3 is a strong, colonic epithelial-cell-derived, lamina propria fibroblast-stimulating factor. Gut (2007) 56:43-51. doi: 10.1136/gut.2005.081646

52. Nio-Kobayashi J, Takahashi-Iwanaga H, Iwanaga T. Immunohistochemical localization of six galectin subtypes in the mouse digestive tract. J Histochem Cytochem. (2009) 57:41-50. doi: 10.1369/jhc.2008.952317

53. Crocker PR, Paulson JC, Varki A. Siglecs and their roles in the immune system. Nat Rev Immunol. (2007) 7:255-66. doi: 10.1038/nri2056

54. Reilly MKO, Paulson JC, O’Reilly MK. Siglecs as targets for therapy in immune-cell-mediated disease. Trends Pharmacol Sci. (2009) 30:240-48. doi: 10.1016/j.tips.2009.02.005

55. Osborn L. Leukocyte adhesion to endothelium in inflammation. Cell (1990) 62:3-6. doi: 10.1016/0092-8674(90)90230-C

56. Springer TA. Traffic signals for lymphocyte recirculation and leukocyte emigration: the multistep paradigm. Cell (1994) 76:301-14. doi: 10.1016/0092-8674(94)90337-9

57. Lasky LA. Selectin-carbohydrate interactions and the initiation of the inflammatory response. Annu Rev Biochem. (1995) 64:113-39. doi: 10.1146/annurev.bi.64.070195.000553

58. McEver RP. Role of selectins in leukocyte adhesion to platelets and endothelium. Ann N Y Acad Sci. (1994) 714:185-89. doi: 10.1111/j.1749-6632.1994.tb12043.x

59. Schwertmann A, Rudloff S, Kunz C. Potential ligands for cell adhesion molecules in human milk. Ann Nutr Metab. (1996) 40:252-62. doi: $10.1159 / 000177965$

60. Geijtenbeek TBH, Gringhuis SI. Signalling through C-type lectin receptors: shaping immune responses. Nat Rev Immunol. (2009) 9:465-79. doi: $10.1038 /$ nri2569 
61. Cohen-Kedar S, Baram L, Elad H, Brazowski E, Guzner-Gur H, Dotan I. Human intestinal epithelial cells respond to beta-glucans via Dectin-1 and Syk. Eur J Immunol. (2014) 44:3729-40. doi: 10.1002/eji. 201444876

62. Volman JJ, Mensink RP, Buurman WA, Onning G, Plat J. The absence of functional dectin-1 on enterocytes may serve to prevent intestinal damage. Eur J Gastroenterol Hepatol. (2010) 22:88-94. doi: 10.1097/MEG.0b013e32832a20dc

63. Rochereau N, Drocourt D, Perouzel E, Pavot V, Redelinghuys P, Brown GD, et al. Dectin-1 is essential for reverse transcytosis of glycosylated SIgAantigen complexes by intestinal M cells. PLoS Biol. (2013) 11:e1001658. doi: 10.1371 /journal.pbio. 1001658

64. Quintin J, Saeed S, Martens JHA, Giamarellos-bourboulis EJ, Ifrim DC, Logie C, et al. Candida albicans infection affords protection against reinfection via functional reprogramming of monocytes. (2012) 12:223-32. doi: 10.1016/j.chom.2012.06.006

65. Quintin J, Cheng S-C, van der Meer JW, Netea MG. Innate immune memory: towards a better understanding of host defense mechanisms. Curr Opin Immunol. (2014) 29C:1-7. doi: 10.1016/j.coi.2014.02.006

66. Morrow AL, Meinzen-Derr J, Huang P, Schibler KR, Cahill T, Keddache $\mathrm{M}$, et al. Fucosyltransferase 2 non-secretor and low secretor status predicts severe outcomes in premature infants. J Pediatr. (2011) 158:745-51. doi: 10.1016/j.jpeds.2010.10.043

67. Morrow AL, Ruiz-Palacios GM, Altaye M, Jiang X, Lourdes Guerrero M, Meinzen-Derr JK, et al. Human milk oligosaccharides are associated with protection against diarrhea in breast-fed infants. J Pediatr. (2004) 145:297303. doi: 10.1016/j.jpeds.2004.04.054

68. Newburg DS, Ruiz-Palacios GM, Altaye M, Chaturvedi P, Meinzen-Derr J, Guerrero $M$ de $L$, et al. Innate protection conferred by fucosylated oligosaccharides of human milk against diarrhea in breastfed infants. Glycobiology (2004) 14:253-63. doi: 10.1093/glycob/cwh020

69. Stepans MB, Wilhelm SL, Hertzog M, Rodehorst TK, Blaney S, Clemens B, et al. Early consumption of human milk oligosaccharides is inversely related to subsequent risk of respiratory and enteric disease in infants. Breastfeed Med. (2006) 1:207-15. doi: 10.1089/bfm.2006.1.207

70. Sprenger N, Odenwald H, Kukkonen AK, Kuitunen M, Savilahti E, Kunz C. FUT2-dependent breast milk oligosaccharides and allergy at 2 and 5 years of age in infants with high hereditary allergy risk. (2017) 56:1293-301. doi: 10.1007/s00394-016-1180-6

71. Puccio G, Alliet P, Cajozzo C, Janssens E, Corsello G, Sprenger N, et al. Effects of Infant formula with human milk oligosaccharides on growth and morbidity: a randomized multicenter trial. J Pediatr Gastroenterol Nutr. (2017) 64:624-31. doi: 10.1097/MPG.0000000000001520

72. Goehring KC, Marriage BJ, Oliver JS, Wilder JA, Barrett EG, Buck RH. Similar to those who are breastfed, infants fed a formula containing 2 '-fucosyllactose have lower inflammatory cytokines in a randomized controlled trial. J Nutr. (2016) 146:2559-66.doi: 10.3945/jn.116.236919

73. Bode L, Kuhn L, Kim HY, Hsiao L, Nissan C, Sinkala M, et al. Human milk oligosaccharide concentration and risk of postnatal transmission of HIV through breastfeeding. Am J Clin Nutr. (2012) 96:831-39. doi: 10.3945/ajcn.112.039503

74. Van Niekerk E, Autran CA, Nel DG, Kirsten GF, Blaauw R, Bode L. Human milk oligosaccharides differ between HIV-infected and HIVuninfected mothers and are related to necrotizing enterocolitis incidence in their preterm very-low-birth-weight infants. J Nutr. (2014) 144:1227-33. doi: 10.3945/jn.113.187799

75. Kuhn L, Kim H-Y, Hsiao L, Nissan C, Kankasa C, Mwiya M, et al. Oligosaccharide composition of breast milk influences survival of uninfected children born to HIV-infected mothers in Lusaka, Zambia. J Nutr. (2015) 145:66-72. doi: 10.3945/jn.114.199794

76. Biesbroek G, Bosch AA, Wang X, Keijser BJ, Veenhoven RH, Sanders EA, et al. The impact of breastfeeding on nasopharyngeal microbial communities in infants. Am J Respir Crit Care Med. (2014) 190:298-308. doi: 10.1164/rccm.201401-0073OC

77. Meli F, Puccio G, Cajozzo C, Ricottone GL, Pecquet S, Sprenger N, et al. Growth and safety evaluation of infant formulae containing oligosaccharides derived from bovine milk: a randomized, double-blind, noninferiority trial. BMC Pediatr. (2014) 14:306. doi: 10.1186/s12887-014-0306-3
78. Bode L. Human milk oligosaccharides: prebiotics and beyond. Nutr Rev. (2009) 67(Suppl. 2):S183-91. doi: 10.1111/j.1753-4887.2009.00239.x

79. Bode L, Jantscher-Krenn E. Structure-function relationships of human milk oligosaccharides. Adv Nutr. (2012) 3:383S-391S. doi: 10.3945/an.111.001404

80. Smilowitz JT, Lebrilla CB, Mills DA, German JB, Freeman SL. Breast milk oligosaccharides: structure-function relationships in the neonate. (2014) 34:143-69. doi: 10.1146/annurev-nutr-071813-105721

81. Barile D, Rastall R A. Human milk and related oligosaccharides as prebiotics. Curr Opin Biotechnol. (2013) 24:214-9. doi: 10.1016/j.copbio.2013.01.008

82. ten Bruggencate SJM, Bovee-Oudenhoven IMJ, Feitsma AL, van Hoffen E, Schoterman MHC. Functional role and mechanisms of sialyllactose and other sialylated milk oligosaccharides. Nutr Rev. (2014) 72:377-89. doi: 10.1111/nure.12106

83. Jeurink PV, van Esch BC, Rijnierse A, Garssen J, Knippels LM. Mechanisms underlying immune effects of dietary oligosaccharides. Am J Clin Nutr. (2013) 98:572S-7S. doi: 10.3945/ajcn.112.038596

84. Peterson R, Cheah WY, Grinyer J, Packer N. Glycoconjugates in human milk: protecting infants from disease. Glycobiology (2013) 23:1425-38. doi: 10.1093/glycob/cwt072

85. Etzold S, Bode L. Glycan-dependent viral infection in infants and the role of human milk oligosaccharides. Curr Opin Virol. (2014) 7:101-7. doi: 10.1016/j.coviro.2014.06.005

86. Newburg DS. Neonatal protection by an innate immune system of human milk consisting of oligosaccharides and glycans. J Anim Sci. (2009) 87:26-34. doi: $10.2527 /$ jas.2008-1347

87. Newburg DS, Ruiz-Palacios GM, Morrow AL. Human milk glycans protect infants against enteric pathogens. Annu Rev Nutr. (2005) 25:37-58. doi: 10.1146/annurev.nutr.25.050304.092553

88. Kunz C, Kunz S, Rudloff S. Bioactivity of human milk oligosaccharides. In: Moreno FJ, Sanz ML, editors. Food Oligosaccharides: Production, Analysis and Bioactivity. Chichester; Hoboken, NJ: John Wiley and Sons Ltd (2014) p. 5-20.

89. Morrow AL, Ruiz-Palacios GM, Altaye M, Jiang X, Guerrero ML, Meinzen-Derr JK, et al. Human milk oligosaccharide blood group epitopes and innate immune protection against campylobacter and calicivirus diarrhea in breastfed infants. Adv Exp Med Biol. (2004) 554:443-6. doi: 10.1007/978-1-4757-4242-8_61

90. Martín-Sosa S, Martín M-J, Hueso P, MartÃ-n-sosa S, MartÃ-n M J, MartinSosa $S$, et al. The sialylated fraction of milk oligosaccharides is partially responsible for binding to enterotoxigenic and uropathogenic Escherichia coli human strains. J Nutr. (2002) 132:3067-72. doi: 10.1093/jn/131.10.3067

91. Schijf MA, Kerperien J, Bastiaans J, Szklany K, Meerding J, Boon L, et al. Alterations in regulatory $\mathrm{T}$ cells induced by specific oligosaccharides improve vaccine responsiveness in mice. PLoS ONE. (2013) 8:e75148. doi: 10.1371/journal.pone.0075148

92. Duska-mcewen G, Senft AP, Ruetschilling TL, Barrett EG, Buck RH. Human milk oligosaccharides enhance innate immunity to respiratory syncytial virus and influenza in vitro. Food Nutr Sci. (2014) 5:1387-98. doi: $10.4236 /$ fns.2014.514151

93. Morrow AL, Ruiz-Palacios GM, Jiang X, Newburg DS. Symposium : innate immunity and human milk human-milk glycans that inhibit pathogen binding protect breast-feeding infants against infectious diarrhea 1, 2. J Nutr. (2005) 135:1304-07. doi: 10.1093/jn/135.5.1304

94. Coppa G V., Zampini L, Galeazzi T, Facinelli B, Ferrante L, Capretti R, et al. Human milk oligosaccharides inhibit the adhesion to Caco-2 cells of diarrheal pathogens: Escherichia coli, Vibrio cholerae, and Salmonella fyris. Pediatr Res. (2006) 59:377-82. doi: 10.1203/01.pdr.0000200805.45593.17

95. Hickey RM. The role of oligosaccharides from human milk and other sources in prevention of pathogen adhesion. Int Dairy J. (2012) 22:141-46. doi: 10.1016/j.idairyj.2011.09.012

96. Weichert S, Jennewein S, Hüfner E, Weiss C, Borkowski J, Putze $J$, et al. Bioengineered $2^{\prime}$-fucosyllactose and 3-fucosyllactose inhibit the adhesion of Pseudomonas aeruginosa and enteric pathogens to human intestinal and respiratory cell lines. Nutr Res. (2013) 33:831-38. doi: 10.1016/j.nutres.2013.07.009

97. Angeloni S, Ridet JL, Kusy N, Gao H, Crevoisier F, Guinchard S, et al. Glycoprofiling with micro-arrays of glycoconjugates and lectins. Glycobiology (2005) 15:31-41. doi: 10.1093/glycob/cwh143 
98. Facinelli B, Marini E, Magi G, Zampini L, Santoro L, Catassi C, et al. Breast milk oligosaccharides : effects of $2^{\prime}$-fucosyllactose and $6^{\prime}$-sialyllactose on the adhesion of Escherichia coli and Salmonella fyris to Caco-2 cells. J Matern Neonatal Med. (2018) 21:1-3 doi: 10.1080/14767058.2018.1450864

99. El-Hawiet A, Kitova EN, Klassen JS. Recognition of human milk oligosaccharides by bacterial exotoxins. Glycobiology (2015) 25:845-54. doi: $10.1093 /$ glycob/cwv025

100. Nguyen TT, Kim JW, Park JS, Hwang KH, Jang TS, Kim CH, et al. Identification of oligosaccharides in human milk bound onto the toxin a carbohydrate binding site of clostridium difficile. J Microbiol Biotechnol. (2016) 26:659-65. doi: 10.4014/jmb.1509.09034

101. Chen P, Reiter T, Huang B, Kong N, Weimer B. Prebiotic oligosaccharides potentiate host protective responses against L. Monocytogenes infection. Pathogens (2017) 6:E68. doi: 10.3390/pathogens6040068

102. Lin AE, Autran CA, Szyszka A, Escajadillo T, Huang M, Godula K, et al. Human milk oligosaccharides inhibit growth of group B Streptococcus. J Biol Chem. (2017) 292:11243-249. doi: 10.1074/jbc.M117.789974

103. Gonia S, Tuepker M, Heisel T, Autran C, Bode L, Gale CA. Human milk oligosaccharides inhibit Candida albicans invasion of human premature intestinal epithelial cells. J Nutr. (2015) 145:1992-8. doi: $10.3945 /$ jn. 115.214940

104. Bondue P, Crèvecoeur S, Brose F, Daube G, Seghaye MC, Griffiths MW, et al. Cell-free spent media obtained from Bifidobacterium bifidum and Bifidobacterium crudilactis grown in media supplemented with $3^{\prime}$-sialyllactose modulate virulence gene expression in Escherichia coli O157: H7 and Salmonella Typhimurium. Front. Microbiol. (2016). 7:1460. doi: $10.3389 /$ fmicb. 2016.01460

105. Yu Z-T, Nanthakumar NN, Newburg DS. The human milk oligosaccharide $2^{\prime}$-fucosyllactose quenches Campylobacter jejuni-induced inflammation in human epithelial cells HEp-2 and HT-29 and in mouse intestinal mucosa. J Nutr. (2016) 146:1980-90. doi: 10.3945/jn.116.230706

106. He Y, Liu S, Kling DE, Leone S, Lawlor NT, Huang Y, et al. The human milk oligosaccharide 2 -fucosyllactose modulates CD14 expression in human enterocytes, thereby attenuating LPS-induced inflammation. Gut (2016) 65:33-46. doi: 10.1136/gutjnl-2014-307544

107. Cilieborg MS, Sangild PT, Jensen ML, Østergaard M V., Christensen L, Rasmussen SO, et al. $\alpha 1,2$-Fucosyllactose does not improve intestinal function or prevent Escherichia coli F18 diarrhea in newborn pigs. J Pediatr Gastroenterol Nutr. (2017) 64:310-18. doi: 10.1097/MPG.0000000000001276

108. Shang J, Piskarev VE, Xia M, Huang P, Jiang X, Likhosherstov $\mathrm{LM}$, et al. Identifying human milk glycans that inhibit norovirus binding using surface plasmon resonance. Glycobiology (2013) 23:1491-8. doi: $10.1093 /$ glycob/cwt077

109. Koromyslova A, Tripathi S, Morozov V, Schroten H, Hansman GS. Human norovirus inhibition by a human milk oligosaccharide. Virology (2017) 508:81-9. doi: 10.1016/j.virol.2017.04.032

110. Hester SN, Chen X, Li M, Monaco MH, Comstock SS, Kuhlenschmidt TB et al. Human milk oligosaccharides inhibit rotavirus infectivity in vitro and in acutely infected piglets. Br J Nutr. (2013) 110:1233-42. doi: 10.1017/S0007114513000391

111. Li M, Monaco MH, Wang M, Comstock SS, Kuhlenschmidt TB, Fahey Jr GC, et al. Human milk oligosaccharides shorten rotavirus-induced diarrhea and modulate piglet mucosal immunity and colonic microbiota. ISME J. (2014) 8:1609-20. doi: 10.1038/ismej.2014.10

112. Kwon SJ, Na DH, Kwak JH, Douaisi M, Zhang F, Park EJ, et al. Nanostructured glycan architecture is important in the inhibition of influenza A virus infection. Nat Nanotechnol. (2017) 12:48-54. doi: 10.1038/nnano.2016.181

113. Zevgiti S, Zabala JG, Darji A, Dietrich U, Panou-Pomonis E, SakarellosDaitsiotis M. Sialic acid and sialyl-lactose glyco-conjugates: design, synthesis and binding assays to lectins and swine influenza H1N1 virus. J Pept Sci. (2012) 18:52-58. doi: 10.1002/psc.1415

114. Yu Y, Mishra S, Song X, Lasanajak Y, Bradley KC, Tappert MM, et al. Functional glycomic analysis of human milk glycans reveals the presence of virus receptors and embryonic stem cell biomarkers. J Biol Chem. (2012) 287:44784-99. doi: 10.1074/jbc.M112.425819

115. Xiao L, Leusink-Muis T, Kettelarij N, van Ark I, Blijenberg B, Hesen NA, et al. Human milk oligosaccharide $2^{\prime}$-fucosyllactose improves innate and adaptive immunity in an influenza-specific murine vaccination model. Front Immunol. (2018) 9:452. doi: 10.3389/fimmu.2018.00452

116. Jantscher-Krenn E, Zherebtsov M, Nissan C, Goth K, Guner YS, Naidu N, et al. The human milk oligosaccharide disialyllacto-N-tetraose prevents necrotising enterocolitis in neonatal rats. Gut (2012) 61:1417-25. doi: 10.1136/gutjnl-2011-301404

117. Autran CA, Kellman BP, Kim JH, Asztalos E, Blood AB, Spence $\mathrm{ECH}$, et al. Human milk oligosaccharide composition predicts risk of necrotising enterocolitis in preterm infants. Gut (2018) 67:1064-70. doi: 10.1136/gutjnl-2016-312819

118. Autran CA, Schoterman MHC, Jantscher-Krenn E, Kamerling JP, Bode L. Sialylated galacto-oligosaccharides and $2^{\prime}$-fucosyllactose reduce necrotising enterocolitis in neonatal rats. Br J Nutr. (2016) 116:294-9. doi: 10.1017/S0007114516002038

119. Good M, Sodhi CP, Yamaguchi Y, Jia H, Lu P, Fulton WB, et al. The human milk oligosaccharide $2^{\prime}$-fucosyllactose attenuates the severity of experimental necrotising enterocolitis by enhancing mesenteric perfusion in the neonatal intestine. Br J Nutr. (2016) 116:1175-87. doi: 10.1017/S0007114516002944

120. Cilieborg MS, Bering SB, Ostergaard MV, Jensen ML, Krych L, Newburg DS, et al. Minimal short-term effect of dietary $2^{\prime}$-fucosyllactose on bacterial colonisation, intestinal function and necrotising enterocolitis in preterm pigs. Br J Nutr. (2016) 116:834-41. doi: 10.1017/S0007114516002646

121. He Y, Liu S, Leone S, Newburg DS. Human colostrum oligosaccharides modulate major immunologic pathways of immature human intestine. Mucosal Immunol. (2014) 7:1326-39. doi: 10.1038/mi.2014.20

122. Kuntz S, Rudloff S, Kunz C. Oligosaccharides from human milk influence growth-related characteristics of intestinally transformed and non-transformed intestinal cells. Br J Nutr. (2008) 99:462-71. doi: 10.1017/S0007114507824068

123. Ortega-González M, Ocón B, Romero-Calvo I, Anzola A, Guadix E, Zarzuelo A, et al. Nondigestible oligosaccharides exert nonprebiotic effects on intestinal epithelial cells enhancing the immune response via activation of TLR4-NFKB. Mol Nutr Food Res. (2014) 58:384-93. doi: 10.1002/mnfr.201300296

124. Zenhom, M. Hyder A, de Vrese M, Heller KJ, Roeder T, Schrezenmeir J. Prebiotic oligosaccharides reduce proinflammatory cytokines in intestinal caco-2 cells via activation of PPARg and peptidoglycan recognition protein. J. Nutr. (2011) 141:971-7. doi: 10.3945/jn.110.136176

125. Lane JA, O'Callaghan J, Carrington SD, Hickey RM. Transcriptional response of HT-29 intestinal epithelial cells to human and bovine milk oligosaccharides. Br J Nutr. (2013) 110:2127-37. doi: 10.1017/S0007114513001591

126. Eiwegger T, Stahl B, Haidl P, Schmitt J, Boehm GG, Dehlink E, et al. Prebiotic oligosaccharides: in vitro evidence for gastrointestinal epithelial transfer and immunomodulatory properties. Pediatr Allergy Immunol. (2010) 21:117988. doi: 10.1111/j.1399-3038.2010.01062.x

127. Atochina O, Da'dara A, Walker M, Harn DA. The immunomodulatory glycan LNFPIII initiates alternative activation of murine macrophages in vivo. Immunology (2008) 125:111-21. doi: 10.1111/j.1365-2567.2008. 02826.x

128. Atochina O, Daly-Engel T, Piskorska D, McGuire E, Harn DA. A schistosome-expressed immunomodulatory glycoconjugate expands peritoneal Gr1(+) macrophages that suppress naive CD4 $(+) \mathrm{T}$ cell proliferation via an IFN-gamma and nitric oxide-dependent mechanism. $J$ Immunol. (2001) 167:4293-302. doi: 10.4049/jimmunol.167.8.4293

129. Atochina O, Harn D. LNFPIII/LeX-stimulated macrophages activate natural killer cells via CD40-CD40L interaction. Clin Diagn Lab Immunol. (2005) 12:1041-49. doi: 10.1128/CDLI.12.9.1041-1049.2005

130. Velupillai P, Harn DA. Oligosaccharide-specific induction of interleukin 10 production by $\mathrm{B} 220+$ cells from schistosome-infected mice: a mechanism for regulation of CD4+ T-cell subsets. Proc Natl Acad Sci USA. (1994) 91:18-22. doi: 10.1073/pnas.91.1.18

131. Yazdanbakhsh M, Kremsner PG, Van Ree R. Immunology: allergy, parasites, and the hygiene hypothesis. Science (2002) 296:490-4. DOI: 10.1126/science.296.5567.490

132. Harn DA., McDonald J, Atochina O, Da'dara A. Modulation of host immune responses by helminth glycans. Immunol Rev. (2009) 230:247-57. doi: 10.1111/j.1600-065X.2009.00799.x 
133. Velupillai P, dos Reis EA, dos Reis MG, Harn DA. Lewis(x)-containing oligosaccharide attenuates schistosome egg antigen-induced immune depression in human schistosomiasis. Hum Immunol. (2000) 61:225-32. doi: 10.1016/S0198-8859(99)00136-6

134. Van der Kleij D, Van Remoortere A, Schuitemaker JHN, Kapsenberg ML, Deelder AM, Tielens AGM, et al. Triggering of innate immune responses by schistosome egg glycolipids and their carbohydrate epitope GalNAc beta 1-4(Fuc alpha 1-2Fuc alpha 1-3)GlcNAc. J Infect Dis. (2002) 185:531-9. doi: $10.1086 / 338574$

135. Comstock SS, Wang M, Hester SN, Li M, Donovan SM. Select human milk oligosaccharides directly modulate peripheral blood mononuclear cells isolated from 10-d-old pigs. Br J Nutr. (2014) 111:819-28. doi: $10.1017 /$ S0007114513003267

136. Bhargava P, Li C, Stanya KJ, Jacobi D, Dai L, Liu S, et al. Immunomodulatory glycan LNFPIII alleviates hepatosteatosis and insulin resistance through direct and indirect control of metabolic pathways. Nat Med. (2012) 18:166572. doi: $10.1038 / \mathrm{nm} .2962$

137. Zhu B, Trikudanathan S, Zozulya A, Sandoval-Garcia C, Kennedy J, Atochina $\mathrm{O}$, et al. Immune modulation by Lacto-N-fucopentaose III in experimental autoimmune encephalomyelitis. Clin Immunol. (2012) 142:351-61. doi: 10.1016/j.clim.2011.12.006

138. Dutta P, Hullett DA, Roenneburg DA, Torrealba JR, Sollinger HW, Harn DA, et al. Lacto-N-fucopentaose III, a pentasaccharide, prolongs heart transplant survival. Transplantation (2010) 90:1071-78. doi: 10.1097/TP.0b013e3181f8f296

139. Xiao L, Land BV, Engen PA, Naqib A, Green SJ, Nato A et al. Human milk oligosaccharides protect against the development of autoimmune diabetes in NOD-mice. Sci Rep. (2018) 8:3829. doi: 10.1038/s41598-018-22052-y

140. Marino E, Richards JL, McLeod KH, Stanley D, Yap YA, Knight J, et al. Gut microbial metabolites limit the frequency of autoimmune $\mathrm{T}$ cells and protect against type 1 diabetes. Nat Immunol. (2017) 18:552-62. doi: 10.1038/ni.3713

141. Xiao L, Van't Land B, van de Worp WRPH, Stahl B, Folkerts G, Garssen J. Early-life nutritional factors and mucosal immunity in the development of autoimmune diabetes. Front Immunol. (2017) 8:1219. doi: 10.3389/fimmu.2017.01219

142. Vaarala O, Atkinson MA, Neu J. The "perfect storm" for type 1 diabetes: the complex interplay between intestinal microbiota, gut permeability, and mucosal immunity. Diabetes (2008) 57:2555-62. doi: 10.2337/db08-0331

143. Garrido D, Dallas DC, Mills DA. Consumption of human milk glycoconjugates by infant-associated bifidobacteria: mechanisms and implications. Microbiology (2013) 159:649-64. doi: 10.1099/mic.0.06 4113-0

144. Yu ZT, Chen C, Newburg DS. Utilization of major fucosylated and sialylated human milk oligosaccharides by isolated human gut microbes. Glycobiology (2013) 23:1281-92. doi: 10.1093/glycob/cwt065

145. Matsuki T, Yahagi K, Mori H, Matsumoto H, Hara T, Tajima S, et al. A key genetic factor for fucosyllactose utilization affects infant gut microbiota development. Nat Commun. (2016) 7:11939. doi: 10.1038/ncomms11939

146. Fukuda S, Toh H, Hase K, Oshima K, Nakanishi Y, Yoshimura K, et al. Bifidobacteria can protect from enteropathogenic infection through production of acetate. Nature (2011) 469:543-47. doi: 10.1038/nature09646

147. Kim $\mathrm{CH}$. Immune regulation by microbiome metabolites. Immunology (2018) 154:220-9. doi: 10.1111/imm.12930

148. Penders J, Thijs C, Piet A Van Den Brandt, Kummeling I, Snijders B, Stelma F, et al. Gut microbiota composition and development of atopic manifestations in infancy: the KOALA Birth Cohort Study. Gut (2007) 56:661-67. doi: 10.1136/gut.2006.100164

149. van Nimwegen FA, Penders J, Stobberingh EE, Postma DS, Koppelman GH, Kerkhof M, et al. Mode and place of delivery, gastrointestinal microbiota, and their influence on asthma and atopy. J Allergy Clin Immunol. (2011) 128:948-55. doi: 10.1016/j.jaci.2011.07.027

150. Wopereis H, Oozeer R, Knipping K, Belzer C, Knol J. The first thousand days - intestinal microbiology of early life: establishing a symbiosis. Pediatr Allergy Immunol. (2014) 25:428-38. doi: 10.1111/pai.12232

151. Johansson MA, Sjogren YM, Persson JO, Nilsson C, Sverremark-Ekstrom E. Early colonization with a group of lactobacilli decreases the risk for allergy at five years of age despite allergic heredity. PLoS ONE (2011) 6:e23031. doi: 10.1371/journal.pone.0023031
152. Thorburn AN, Mckenzie CI, Shen S, Stanley D, Macia L, Mason LJ, et al. Evidence that asthma is a developmental origin disease influenced by maternal diet and bacterial metabolites. Nat Commun. (2015) 6:1-13. doi: $10.1038 /$ ncomms 8320

153. Trompette A, Gollwitzer ES, Yadava K, Sichelstiel AK, Sprenger N, Ngombru C, et al. Gut microbiota metabolism of dietary fiber influences allergic airway disease and hematopoiesis. Nat Med. (2014) 20:159-66. doi: $10.1038 / \mathrm{nm} .3444$

154. Marsland BJ, Gollwitzer ES. Host-microorganism interactions in lung diseases. Nat Rev Immunol. (2014) 14:827-35. doi: 10.1038/nri3769

155. Tan J, McKenzie C, Vuillermin PJ, Goverse G, Vinuesa CG, Mebius RE, et al. Dietary fiber and bacterial SCFA enhance oral tolerance and protect against food allergy through diverse cellular pathways. Cell Rep. (2016) 15:2809-24. doi: 10.1016/j.celrep.2016.05.047

156. Maslowski KM, Vieira AT, Ng A, Kranich J, Sierro F, Yu D, et al. Regulation of inflammatory responses by gut microbiota and chemoattractant receptor GPR43. Nature (2010) 461:1282-86. doi: 10.1038/nature08530

157. Matheson MC, Allen KJ, Tang MLK. Understanding the evidence for and against the role of breastfeeding in allergy prevention. Clin. Exp Allergy (2012) 42:827-51. doi: 10.1111/j.1365-2222.2011.03925.x

158. Van Odijk JV, Kull I, Borres MP, Brandtzaeg P, Edberg U, Kuitunen $\mathrm{M}$, et al. Breastfeeding and allergic disease : a multidisciplinary review of the literature (1966-2001) on the mode of early feeding in infancy and its impact on later atopic manifestations. Allergy (2003) 58:833-43. doi: 10.1034/j.1398-9995.2003.00264.x

159. Lodge C, Tan D, Lau M, Dai X, Tham R, Lowe A, et al. Breastfeeding and asthma and allergies: a systematic review and meta-analysis. Acta Paediatr. (2015) 104:38-53. doi: 10.1111/apa.13132

160. Munblit D, Boyle RJ, Warner JO. Factors affecting breast milk composition and potential consequences for development of the allergic phenotype. Clin Exp Allergy (2014) 45:583-601. doi: 10.1111/cea.12381

161. Castillo-Courtade L, Han S, Lee S, Mian FM, Buck R, Forsythe P. Attenuation of food allergy symptoms following treatment with human milk oligosaccharides in a mouse model. Allergy (2015) 70:1091-102. doi: $10.1111 /$ all.12650

162. Eigenmann PA. Evidence of preventive effect of probiotics and prebiotics for infantile eczema. Curr Opin Allergy Clin Immunol. (2013) 13:426-31. doi: 10.1097/ACI.0b013e3283630bad

163. Bruzzese E, Volpicelli M, Squeglia V, Bruzzese D, Salvini F, Bisceglia M, et al. A formula containing galacto- and fructo-oligosaccharides prevents intestinal and extra-intestinal infections: an observational study. Clin Nutr. (2009) 28:156-61. doi: 10.1016/j.clnu.2009.01.008

164. Bruzzese E, Volpicelli M, Squaglia M, Tartaglione A., Guarino A. Impact of prebiotics on human health. Dig Liver Dis. (2006) 38:S283-87. doi: 10.1016/S1590-8658(07)60011-5

165. Arslanoglu S, Moro GE, Boehm G. Early supplementation of prebiotic oligosaccharides protects formula-fed infants against infections during the first 6 months of life. J Nutr. (2007) 137:2420-4. doi: 10.1093/jn/137.11.2420

166. Osborn DA, Sinn JKH. Prebiotics in infants for prevention of allergy. Cochrane database Syst Rev. (2013) 3:CD006474. doi: 10.1002/14651858.CD006474.pub3

167. Lomax AR, Calder PC. Prebiotics, immune function, infection and inflammation: a review of the evidence. Br J Nutr. (2009) 101:633-58. doi: $10.1017 /$ S0007114508055608

Conflict of Interest Statement: VT and RvN are employees of FrieslandCampina.

The remaining author declares that the research was conducted in the absence of any commercial or financial relationships that could be construed as a potential conflict of interest.

Copyright (c) 2018 Triantis, Bode and van Neerven. This is an open-access article distributed under the terms of the Creative Commons Attribution License (CC BY). The use, distribution or reproduction in other forums is permitted, provided the original author(s) and the copyright owner(s) are credited and that the original publication in this journal is cited, in accordance with accepted academic practice. No use, distribution or reproduction is permitted which does not comply with these terms. 